\title{
Genetic Diversity of Respiratory Syncytial Virus Isolated During an Epidemic Period From Children of Northeastern Brazil
}

\author{
Fernanda Edna Araújo Moura, ${ }^{1}$ Andrea Blanc, ${ }^{2}$ Sandra Frabasile, ${ }^{2}$ Adriana Delfraro, ${ }^{2}$ \\ María José de Sierra, ${ }^{2}$ Lorena Tome, ${ }^{2}$ Eduardo Antônio Gonçalves Ramos, ${ }^{1}$ \\ Marilda Mendonça Siqueira, ${ }^{3}$ and Juan Arbiza ${ }^{2 *}$ \\ ${ }^{1}$ Laboratório de Patología e Doenças Virais, Centro de Pesquisa Gonçalo Moniz, FIOCRUZ, Rua Waldemar Falcão, \\ Brotas, Salvador, Bahia, Brazil \\ ${ }_{2}^{2}$ Sección Virología, Facultad de Ciencias-Universidad de la República, Igua, Montevideo-Uruguay \\ ${ }^{3}$ Laboratório de Vírus Respiratórios, Instituto Oswaldo Cruz, Avenida Brasil, Manguinhos, Rio de Janeiro, Brazil
}

Outbreaks of human respiratory syncytial virus (HRSV) are the leading cause of serious acute lower respiratory viral disease in many countries in different continents. Data on clinical and epidemiological aspects of HRSV infections in this country have been reported, but there is lack of data regarding the molecular epidemiology of this virus in Salvador. The genetic variability of HRSV isolated during an outbreak in Salvador, Brazil (1999) has been analysed. Partial sequences of the $G$ protein gene of 13 isolates from antigenic group $A$ and 4 isolates from antigenic group B of HRSV were determined. Nucleotide sequences of $\mathrm{C}$-terminal $\mathrm{G}$ gene were compared to sequences of HRSV isolates from countries of South America and from the rest of the world available at the GenBank. Brazilian group A and B isolates were clustered into previously characterised genotypes: GA5, GA2, GA7, and GB3, SAB3, respectively. This is the first study of GA7 and SAB3 genotypes circulation in South American countries. It is interesting to point out that viruses isolated in Salvador appear to be closer related with those from Montevideo-Uruguay and Buenos Aires, Argentina strains, suggesting circulation of similar strains among different South American countries in different seasons. Moreover, viruses closely related genetically circulated in the same year in Salvador and distant places such as Mozambique, supporting the previous suggestion on the complexity of HRSV strain circulation patterns, and the high capability of HRSV spreading world-wide. J. Med. Virol. 74:156-160, 2004. ๑ 2004 Wiley-Liss, Inc.

KEY WORDS: RSV infections; genetic diversity; Salvador, Brazil

\section{INTRODUCTION}

The importance of human respiratory syncytial virus (HRSV) in respiratory infections in infants, young children, the elderly and the immunocompromised has been well documented [Selwyn, 1990; Englund et al., 1991; Falsey et al., 1995]. Infections by HRSV occur as annual epidemics throughout the world, showing different patterns of occurrence associated with different climate regions [Weber et al., 1998]. Sharp outbreaks during the winter months in temperate regions contrast with extended periods related to the rainy season in tropical countries [reviewed by Cane, 2001; Moura et al., 2003a].

Brazil is a large country and this contributes to the climatic diversity observed in its different regions. This characteristic can influence the diverse occurrence of the HRSV infections that has been observed in cities from Northern, Northeastern, Southeastern and Southern regions [Nascimento et al., 1991; Mello and Silva, 1992; Vieira et al., 2001; Checon et al., 2002; Straliottoet al., 2002]. Salvador, the capital of Bahia, Northeastern Brazil, has an estimated population of $2,800,000$, at sea level, $13^{\circ}$ south of the equator. The climate is tropical with high relative humidity, rainfall

Grant sponsor: European Union (to M.M.S. \& J.A.); Grant number: IC18CT980374.

Juan Arbiza's present address is Laboratório de Vírus Respiratórios, Pavilhão Cardoso Fontes. Instituto Oswaldo Cruz (FIOCRUZ/CNPq), Avenida Brasil 4365, CEP: 21.045-900. Manguinhos, Rio de Janeiro, Brazil.

*Correspondence to: Juan Arbiza, Sección Virología, Facultad de Ciencias, Universidad de la República, Igua 4225 (11400), Montevideo-Uruguay. E-mail: jarbiza@fcien.edu.uy

Accepted 21 April 2004

DOI 10.1002/jmv.20159

Published online in Wiley InterScience

(www.interscience.wiley.com) 
throughout the year with a peak in April. In this region as in the Northern region, HRSV infections are related to the rainy season, while in the Southern region the association is with the coldest months [Mello and Silva, 1992; Straliotto et al., 2002; Moura et al., 2003a]. The majority of HRSV infections in Northern, Northeastern and Southeastern Brazil occur during the first semester, whereas in cities of the Southern region they extend for some months in the second semester [Nascimento et al., 1991; Mello and Silva, 1992; Checon et al., 2002; Straliotto et al., 2002; Moura et al., 2003a].

Two principal antigenic groups $\mathrm{A}$ and $\mathrm{B}$ have been identified by their reactivity with monoclonal antibodies [Anderson et al., 1985; Mufson et al., 1985].

Studies on the circulation of the main HRSV group A and $B$ strains in different Brazilian cities have found that both antigenic groups A and B co-circulate in the majority of the epidemic periods, although group A viruses predominated [Siqueira et al., 1991; Cintra et al., 2001; Straliotto et al., 2001; Moura et al., 2003b].

Several lineages within each group have been identified by numerous strains sequenced world-wide [Cane and Pringle, 1991, 1992, 1995a,b; Garcia et al., 1994; Peret et al., 1998, 2000; Martínez et al., 1999; Roca et al., 2001; Venter et al., 2001; Frabasile et al., 2003], focusing the genetic variability of HRSV on the G protein, the viral gene product with the highest degree of antigenic and genetic diversity among viral isolates [reviewed by Melero et al., 1997].

In order to gain information on the genetic diversity of HRSV in Brazil, we evaluated the genetic variability of both group A and B HRSV strains isolated during an epidemic period in a single community (Salvador, Bahia, Brazil) by sequencing the hypervariable $C$-terminal third of the $\mathrm{G}$ protein ectodomain. The co-circulation pattern and genetic variability of both group A and B isolates are described and compared with HRSV isolates from Salvador with genotypes identified in other countries of South America and South Africa as well as HRSV sequences from other countries available at the GenBank.

\section{MATERIALS AND METHODS}

\section{Specimen Collection and Virus Isolation}

Nasopharyngeal aspirates were collected by mechanical suction from infants and children under 5 years of age who were attending the emergence room and paediatric wards of the Professor Hosannah de Oliveira Pediatric Center (PHOPC) in Salvador, Brazil with upper- or lower respiratory tract infection from January to December, 1999.

All samples were tested by indirect immunofluorescence for antigen detection of RSV, adenovirus, influenza and parainfluenza virus (Respiratory Viruses Panel I Viral Screening and Identification Kit) according to manufacturer's instructions (Chemicon International, Inc., Temecula, CA, Catalog no. 3105).

For virus isolation, one aliquot of $100 \mu \mathrm{l}$ of sample was inoculated onto HEp-2 cells, and the cultures with characteristic cytopathic effect were confirmed by immunofluorescence. Isolates were stored at $-70^{\circ} \mathrm{C}$ until further passages in HEp-2 cells for RNA extraction.

\section{Reverse Transcription-Polymerase Chain Reaction (RT-PCR) and Sequencing}

Total RNA was extracted from infected cells lysates by a Trizol ${ }^{\circledR}$ procedure according to the manufacturer's recommendations. The extracted viral RNA was used as a template for cDNA synthesis. For this purpose, $2 \mu \mathrm{l}$ of total RNA, $500 \mathrm{ng}$ of antisense primer LG3 (-) $5^{\prime}$ GGCCCGGGAAGCTTTTTTTTTTTTTTT-3'; which has an Ava I site (underlined) for cloning purposes, $10 \mathrm{mM}$ dNTPs, in a final reaction volume of $10.5 \mu \mathrm{l}$ were incubated for $5 \mathrm{~min}$ at $65^{\circ} \mathrm{C}$. This was added to a mixture containing $200 \mathrm{U} / \mu \mathrm{l}$ of MMLV-RT reverse transcriptase (Gibco-BRL, Gaithersburg, MD), $5 \mathrm{U} / \mu$ l of RNase inhibitor (Promega, Madison, WI) and $250 \mathrm{mM}$ Tris- $\mathrm{HCl}$ $\mathrm{pH} 8.3,375 \mathrm{mM} \mathrm{KCl}, 15 \mathrm{mM} \mathrm{MgCl}_{2}, 0.1 \mathrm{M} \mathrm{DTT}$, at $37^{\circ} \mathrm{C}$ for $50 \mathrm{~min}$, the enzyme was inactivated at $70^{\circ} \mathrm{C}$ for $5 \mathrm{~min}$.

To obtain the entire $G$ gene, the PCR assay was carried out in a mixture containing $2 \mu \mathrm{l}$ of cDNA, $5 \mu \mathrm{l} 10 \times$ PCR buffer (200 mM Tris- $\mathrm{HCl}$ pH 8.4, $500 \mathrm{mM} \mathrm{KCl}$ ), $1.5 \mu \mathrm{MgCl}_{2} 50 \mathrm{mM}, 10 \mathrm{mM}$ dNTPs, $5 \mathrm{U}$ of Taq DNA polimerase (Gibco-BRL), $10 \mu \mathrm{M}$ of antisense primer LG3 (-) and a sense primer LG5(+) 5'-GGATCCCGGGGCAAATGCAAACATGTCC-3', which has an Ava I site (underlined) and the first 20 nucleotides of the $\mathrm{G}$ protein from the Long strain. The reaction was carried out in a Thermolyne Amplitron ${ }^{\circledR}$ I. Amplification conditions consisted of $5 \mathrm{~min}$ at $95^{\circ} \mathrm{C}$, followed by 35 cycles of $94^{\circ} \mathrm{C}$ for $1 \mathrm{~min} 30 \mathrm{sec} ; 54^{\circ} \mathrm{C}$ for $2 \mathrm{~min} ; 72^{\circ} \mathrm{C}$ for $1 \mathrm{~min}$ with a final extension at $72^{\circ} \mathrm{C}$ for $7 \mathrm{~min}$.

A seminested-PCR was performed to amplify the $C$ terminal region of $\mathrm{G}$ protein with group specific primers. The reaction conditions were the same but using as a template the first-round PCR products $1 / 20$ dilution and the inner sense primers GA 480(+) 5'-ACAAACCACCAAACAAACCC-3 to the isolates of group A, and GB 496(+) 5'-GATGATTACCATTTTGAAGTGTTCA-3 to the isolates of group B.

Ten microliters of seminested RT-PCR products were run on $1.5 \%$ agarose gel and visualized under UV light after staining with ethidium bromide.

The PCR products were purified with a QIAquick ${ }^{\circledR}$ gel extraction kit (Qiagen, Hilden, Germany). Nucleotide sequencing was carried out in a ABI PRISM ${ }^{\mathrm{TM}} 377$ Sequencer using a fluorescent dye terminator kit (Applied Biosystems, Foster City, CA) with $32.5 \mathrm{ng} / \mu \mathrm{l}$ of primers GA $480(+)$ and GB $496(+)$ to group A and B, respectively.

\section{Phylogenetic Analysis}

Nucleotide sequences from the second variable region of the $G$ gene of group A and B viruses were aligned separately with ClustalX 1,8 [Higgins and Sharp, 1988; Thompson et al., 1997] applying the multiple alignment option. P-distances were calculated with MEGA 2.1 
[Kumar et al., 2001]. Phylogenetic analyses were carried out with Paup* 4.0b10 [Swofford, 2000]. Distances were calculated under Kimura 2 parameter model with a transition/transversion ratio of 3 for group A and 8 for group B. The topological accuracy of the tree was estimated by the bootstrap method, with 500 replicates; only values greater than $65 \%$ were considered to be significant.

Forty-one published sequences from group A and 35 from group B were downloaded from GenBank as reference of different lineages and genotypes.

\section{Nucleotide Sequences Accession Number}

The sequences examined in this study have been submitted to the GenBank with accession numbers: AY472086-AY472102.

\section{RESULTS}

During 1999, a total of 254 specimens collected from infants and children under 5 years of age with upper- or lower respiratory tract infection at the Professor Hosannah de Oliveira Pediatric Center (PHOPC) in Salvador, Brazil were processed for virus diagnosis.

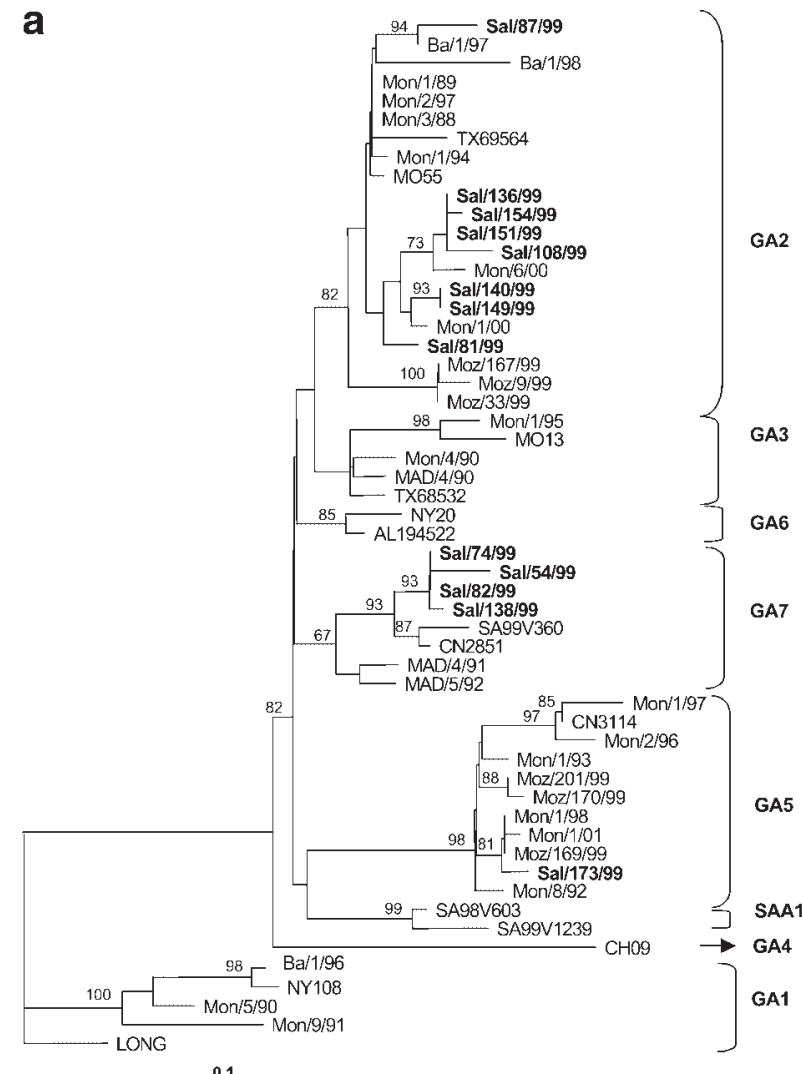

Fig. 1. Phylogenetic trees of group A (a) and B (b) of human respiratory syncytial virus (HRSV) isolates constructed under distance criterion. Reference sequences were downloaded from GenBank and included for comparison: From Montevideo, Uruguay (Mon) and Buenos Aires, Argentina (Ba) [Garcia et al., 1994; Frabasile et al. 2003]; Madrid, Spain (MAD), [Garcia et al., 1994]; United States (TX, Texas; AL, Alabama; NY, New York; MO, Missouri; CH, Rochester,
Fifty-two samples were HRSV positive by indirect immunofluorescence assay directly from the nasopharyngeal aspirates. Of these, only 17 samples were isolated in HEp-2 cells. Thirteen isolates were classified as group A and four as group B, by an ELISA with monoclonal antibodies specific for each group kindly supplied by Dr. Melero as described by Garcia et al. [1994] and Frabasile et al. [2003].

To define the genetic variability within and between groups, the $3^{\prime}$ terminal third of the $G$ protein gene was sequenced, representing the most variable portion of this protein [reviewed by Melero et al., 1997; Peret et al., 1998; Martínez et al., 1999]. The last 270 nucleotides at the $C$-terminus region of the $G$ gene were used to establish phylogenetic relationships between the Brazilian isolates and published sequences from different genotypes [Peret et al., 1998, 2000; Sullender, 2000; Venter et al., 2001, 2002; Frabasile et al., 2003].

HRSV group A isolates in Salvador clustered into three genotypes assigned previously as GA2, GA5 and GA7, displaying 67-98\% bootstrap values (Fig. 1a). Salvador group B isolates clustered into two previously described genotypes SAB3, supported by $71 \%$ bootstrap value, and genotype GB3 which could not be supported by significant bootstrap statistics.

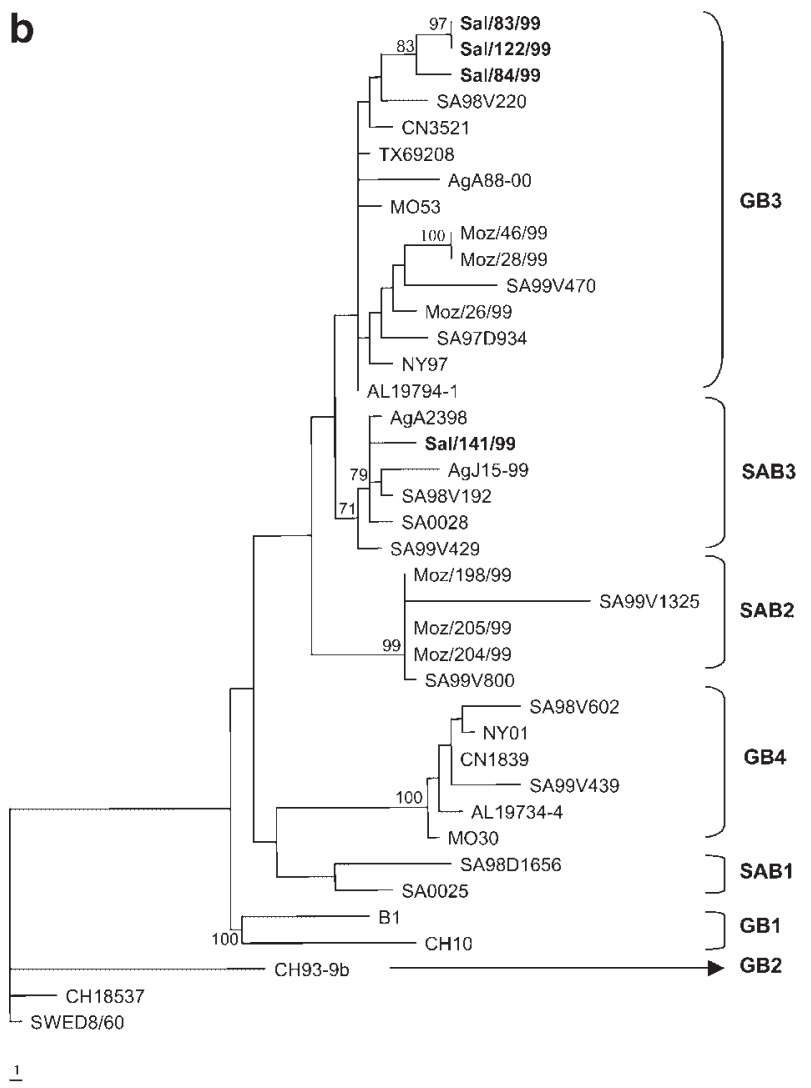

New York); Canada (CN) [Peret et al., 1998]; SA, Soweto, South Africa [Venter et al., 2001]; Ag, Agincourt, South Africa [Venter et al., 2002]; Mozambique (Moz) [Roca et al., 2001]; B1 [Karron et al., 1997]; Long and CH18537 strains [Johnson et al., 1987] were used as outgroup sequences in the trees. Inner numbers represent bootstrap proportion in support to the adjacent node. Genotypes are indicated in brackets. 
TABLE I. Genetic p-Distances Between Individual Sequences Within Each Genotype

\begin{tabular}{llc}
\hline Genotype & \multicolumn{1}{c}{ Sequences compared } & $\begin{array}{c}\mathrm{p} \text {-distance } \\
\text { (ranging between) }\end{array}$ \\
\hline GA2 & Sal and Moz/99 & $0.037-0.067$ \\
& Sal and South American & $0.011-0.052$ \\
GA5 & Sal and Moz/99 & $0.007-0.026$ \\
& Sal and South American & $0.007-0.048$ \\
GA7 & Sal and SA/99 & $0.026-0.041$ \\
GB3 & Sal and SA/99, Moz/99 & $0.034-0.061$ \\
SAB3 & Sal and SA/99 & $0.026-0.037$ \\
\hline
\end{tabular}

Sal, Salvador; Moz, Mozambique; SA, South Africa.

The p-distances between individual sequences of Salvador within each genotype compared with other related strains isolated in the same year in the Southern hemisphere or in different seasons in South America were determined and represented in Table I.

The deduced amino acid sequences of the Salvador group B isolates indicated that all of them shared an expected G protein length of 295 amino acids, while among group $\mathrm{A}$ isolates the deduced amino acid sequence indicated the presence of G protein of two different expected lengths of 297 and 298 amino acids. In all cases for both groups the stop codon was an UAG triplet (data not shown).

\section{DISCUSSION}

HRSV is the most prevalent virus associated with respiratory infections in Brazilian children [Nascimento et al., 1991; Straliotto et al., 2002; Moura et al., 2003a]. In the present study we report on the genetic analysis of HRSV isolated from hospitalised children in Salvador, in the Northeastern region of Brazil, occurring during the epidemic period (February to August) in 1999.

As seen in previous studies from different countries, simultaneous circulation of both groups A and B of HRSV was observed in one community during an epidemic period [Cane and Pringle, 1991; Peret et al., 1998; Carballal et al., 2000; Venter et al., 2002; Arbiza et al., 2003]. Data from other Brazilian regions have shown the co-circulation of both groups in several epidemic periods [Siqueira et al., 1991; Cintra et al., 2001; Straliotto et al., 2001; Moura et al., 2003b].

Although a small amount of samples was analysed in the present study, it was possible to identify different genotypes from both groups A (GA2, GA5, GA7) and B (GB3, SAB3) co-circulating during an epidemic period as was previously reported [Peret et al., 1998, 2000; Roca et al., 2001; Venter et al., 2001, 2002; Frabasile et al., 2003; Madhi et al., 2003]. Phylogenetic analysis revealed that Salvador HRSV isolates clustered with previously assigned group A and B genotypes, confirming that HRSV variants can spread world-wide [Cane et al., 1992].

According to previous studies, some strains of both groups isolated in Salvador are related more closely to strains isolated in distant places in different years than to other strains isolated during the same epidemic in the same place, supporting the idea of the great ability of
HRSV to spread world-wide [Garcia et al., 1994; Cane and Pringle, 1995a,b; Melero et al., 1997].

Isolates from Montevideo, Uruguay and Buenos Aires, Argentina appear to be related more closely with the Salvador strains, suggesting circulation of similar strains among different South American countries in different seasons. For instance, within the GA2 genotype, the Salvador strains are in the same branch together with strains from Montevideo and Buenos Aires, but separately with strains from Mozambique, even those isolated in the same year. Thus, the nucleotide pdistances between Salvador isolates ranged from 0.037 to 0.067 and 0.011 to 0.052 for Mozambique and South American isolates, respectively. Therefore, Brazil, Argentina and Uruguay may be sources of epidemic strains for each other, supporting the idea suggested previously where a transfer of viruses between communities may occur [Peret et al., 2000; Venter et al., 2001].

All the genotypes identified in Salvador during 1999 circulated in countries such as South Africa and Mozambique in a distant continent during the same year. However, the results of the phylogenetic analysis and $\mathrm{p}$-distances indicated that the same genotype does not necessarily suggest that identical strains circulated globally. Thus, some isolates from Salvador, Brazil clustered within the same genotype but on separate branches relative to isolates from Africa (e.g., Sal/54/99 and SA99V360 in GA7 genotype); p-distances between individual sequences from Salvador ranged from 0 to 0.019 (data not shown) and between Salvador and South Africa from 0.026 to 0.041 . However, in other genotypes as GA5 (e.g., Sal/173/99 and Moz/169/99) the isolates from Salvador and Mozambique that are placed in the same branch, have a p-distance of 0.007 between them, indicating that viruses related closely genetically occurred in the same year in distant places, confirming the complexity of HRSV strain circulation patterns.

The Salvador strains group B clustered into different branches in the same genotype respect to Mozambique strains isolated in the same year. This is supported by the $\mathrm{p}$-distances values shown in Table I and the bootstrap value (Fig. 1b).

\section{REFERENCES}

Anderson LJ, Hierholzer JC, Tsou C, Hendry RM, Fernie BN, Stone Y, McIntosh K. 1985. Antigenic characterisation of respiratory syncytial virus strains with monoclonal antibodies. J Infect Dis 151:626-633.

Arbiza J, Delfraro A, Frabasile S, Ruchansky D, Vitureira N, de Sierra MJ, Berois M, Blanc A, Facal L, Negro C, Colina R, Hortal M, Russi JC. 2003. Variable dominance of respiratory syncytial virus groups $\mathrm{A}$ and B in Uruguay during fourteen consecutive years (19882001). Virus Rev Res 8:35-41.

Cane PA. 2001. Molecular epidemiology of respiratory syncytial virus. Rev Med Virol 11:103-116.

Cane PA, Pringle CR. 1991. Respiratory syncytial virus heterogeneity during an epidemic analysis by limited nucleotide sequencing ( $S H$ gene) and restriction mapping ( $N$ gene). J Gen Virol 27:349-357.

Cane PA, Pringle CR. 1992. Molecular epidemiology of respiratory syncytial virus: Rapid identification of subgroup A lineages. J Virol Methods 40:297-306.

Cane PA, Pringle CR. 1995a. Evolution of subgroup A respiratory syncytial virus: Evidence for progressive accumulation of amino acid changes in the attachment protein. J Virol 69:2918-2925. 
Cane PA, Pringle CR. 1995b. Molecular epidemiology of human respiratory syncytial virus. Semin Virol 6:371-378.

Cane PA, Mathews DA, Pringle CR. 1992. Analysis of relatedness of subgroup A respiratory syncytial viruses isolated world-wide. Virus Res 25:15-22.

Carballal G, Videla C, Sequeira M, Mistchenko A, Requeijo P, Arbiza J. 2000. Respiratory syncytial virus: Changes in prevalence of subgroups A and B among Argentinean children, 1990-1996. J Med Virol 61:275-279.

Checon RE, Siqueira MM, Lugon AK, Portes S, Dietze R. 2002. Seasonal pattern of respiratory syncytial virus in a region with a tropical climate in Southeastern Brazil. Am Trop Med Hyg 67:490491.

Cintra OAL, Owe MA, Machado AA, Cerwi MC, Figueiredo LT, Rocha GM, Siqueira MM, Arruda E. 2001. Occurrence and severity of infections caused by subgroup $A$ and $B$ respiratory syncytial virus in children in Southeast Brazil. J Med Virol 65:408-412.

Englund JAL, Anderson LJ, Rhame FS. 1991. Nosocomial transmission of respiratory syncytial virus in immunocompromised adults. J Clin Microbiol 29:115-119.

Falsey AR, Cunningham CK, Barker WH, Kouides RW, Yuen JB, Menegus M, Weiner LB, Bonville CA, Bets RF. 1995. Respiratory syncytial virus and influenza A infections in the hospitalised elderly. J Infect Dis 172:389-394.

Frabasile S, Delfraro A, Facal L, Videla C, Galiano M, de Sierra MJ, Ruchanscky D, Vitureira N, Berois M, Carballal G, Russi J, Arbiza J. 2003. Antigenic and genetic variability of human respiratory syncytial viruses (group A) isolated in Uruguay and Argentina. 1993-2001. J Med Virol 71:305-312.

Garcia O, Martin M, Dopazo J, Arbiza J, Frabasile S, Russi J, Hortal M, Perez-Breña P, Martinez I, Garcia-Barreno B, Melero JA. 1994. Evolutionary pattern of human respiratory syncytial virus (subgroup A): Cocirculating lineages and correlation of genetic and antigenic changes in the G glycoprotein. J Virol 68:5448-5459.

Higgins DG, Sharp PM. 1988. CLUSTAL: A package for performing multiple sequence alignment on a microcomputer. Gene 73:237244.

Johnson PR, Spriggs MK, Olmsted RA, Collins PL. 1987. The G glycoprotein of human respiratory syncytial viruses of subgroups $A$ and B: Extensive sequence divergence between antigenically related proteins. Proc Natl Acad Sci 84:5625-5629.

Karron RA, Buonagurio DA, Georgia AF, Whitehead SS, Adamas JE. 1997. Respiratory syncytial virus (RSV) $\mathrm{SH}$ and $\mathrm{G}$ proteins are not essential for viral replication in vitro: Clinical evaluation and molecular characterization of a cold-passaged, attenuated RSV subgroup B mutant. Proc Natl Acad Sci USA 94:13961-13966.

Kumar S, Tamura K, Jakobsen IB, Nei M. 2001. MEGA2: Molecular evolutionary genetics analysis software. Bioinformatics 12:12441245.

Madhi SA, Venter M, Alexandra R, Lewis H, Kara Y, Karshagen WF, Greef M, Lassen C. 2003. Respiratory syncytial virus associated illness in high-risk children and national characterisation of the circulating virus genotype in South Africa. J Clin Virol 27:180-189.

Martínez I, Valdés O, Delfraro A, Arbiza J, Russi J, Melero JA. 1999 Evolutionary pattern of the $\mathrm{G}$ glycoprotein of human respiratory syncytial virus from antigenic group $B$ : The use of alternative termination codons and lineage diversification. J Gen Virol 80:125130

Melero JA, García-Barreno B, Martínez I, Pringle CR, Cane PA. 1997. Antigenic structure, evolution and immunobiology of human respiratory syncytial virus attachment $(G)$ protein. J Gen Virol 78:2411-2418

Mello WA, Silva C. 1992. Epidemiological aspects of RSV subgroups in Belém, Brazil. Boletin Latino-Americano 1:8.

Moura FEA, Borges LC, Souza LSF, Ribeiro DH, Siqueira MM, Ramo EAG. 2003a. Estudo de infecções respiratórias agudas virais em criancas atendidas em um centro pediátrico em Salvador. (BA). J Bras Pat Med Lab 39:369-376.

Moura FEA, Borges LC, Portes SAR, Ramos EAG, Siqueira MM. 2003b. Respiratory syncytial virus infections during an epidemic period in Salvador, Brazil. Viral antigenic group analysis and description of clinical and epidemiological aspects. Mem Inst Oswaldo Cruz 98 739-743.

Mufson MA, Örvell C, Rafnar B, Morrby E. 1985. Two distinct subtypes of human respiratory syncytial virus. J Gen Virol 66:2111-2124.

Nascimento JP, Siqueira MM, Sutmoller F, Krawczuk MM, Farias V, Ferreira V, Rodrigues MJ. 1991. Longitudinal study of acute respiratory diseases in Rio de Janeiro: Occurrence of respiratory viruses during four consecutive years. Rev Inst Med Trop S. Paulo 33:287-296.

Peret TC, Hall CB, Scnabel KC, Golub JA, Anderson LJ. 1998. Circulation patterns of genetically distinct group A and B strains of human respiratory syncytial virus in a community. J Gen Viro 79:2221-2229.

Peret TC, Hall CB, Hammond GW, Piedra PA, Storch GA, Sullender WM, Tsou C, Anderson LJ. 2000. Circulation patterns of group A and $\mathrm{B}$ human respiratory syncytial virus genotypes in 5 communities in North America. J Infect Dis 181:1891-1896.

Roca A, Loscertales MP, Quintó L, Pérez-Brena P, Vaz N, Alonso PL, Saiz JC. 2001. Genetic variability among group A and B respiratory syncytial viruses in Mozambique: Identification of a new cluster of group B isolates. J Gen Virol 82:103-111.

Selwyn BJ. 1990. The epidemiology of acute respiratory tract infection in Young children: Comparison of findings from several developing countries. Rev Infect Dis 12:S870-S888.

Siqueira MM, Nascimento JP, Anderson LJ. 1991. Antigenic characterization of respiratory syncytial virus group $\mathrm{A}$ and $\mathrm{B}$ isolates in Rio de Janeiro, Brazil. J Clin Microbiol 29:557-559.

Straliotto SM, Nestor SM, Siqueira MM. 2001. Respiratory syncytia virus group A and B in Porto Alegre, Brazil, from 1990 to 1995 and 1998. Mem Inst Oswaldo Cruz 96:155-158.

Straliotto SM, Siqueira MM, Muller RL, Fischer GB, Cunha ML, Nestor SM. 2002. Viral etiology of acute respiratory infections among children in Porto Alegre, RS, Brazil. Rev Soc Bras Med Trop 35:283-291.

Sullender WM. 2000. Respiratory syncytial virus genetic and antigenic diversity. Clin Microbiol Rev 13:1-15.

Swofford DL. 2000. PAUP*: Phylogenetic analysis using parsimony (and other methods), Vol. 4.0b4a. Sunderland, Massachusetts: Sinauer Associates, Inc. Publishers.

Thompson JD, Gibson TJ, Plewniak F, Jeanmougin F, Higgins DG 1997. The Clustal X windows interface: Flexible strategies for multiple sequence alignment aided by quality analysis tools. Nucleic Acids Res 24:4876-4882.

Venter M, Madhi SA, Tiemssen CT, Schoub BD. 2001. Genetic diversity and molecular epidemiology of respiratory syncytial virus over four consecutive seasons in South Africa: Identification of new subgroup A and B genotypes. J Gen Virol 82:2117-2124.

Venter M, Collinson M, Schoub B. 2002. Molecular epidemiological analysis of community circulating respiratory syncytial virus in rural South Africa: Comparison of viruses and genotypes responsible for different disease manifestations. J Med Virol 68:452461.

Vieira SE, Stewien KE, Queiroz DA, Durigon EL, Török TJ, Anderson LJ, Miyao CR, Hein N, Botosso VF, Pahl MM, Gilio AE, Ejzenberg B Okay Y. 2001. Clinical patterns and seasonal trends in respiratory syncytial virus hospitalizations in São Paulo, Brazil. Rev Inst Med Trop São Paulo 43:125-131.

Weber MW, Dackour R, Usen S, Schineider G, Adegbola RA, Cane PA, Jaffar S, Milligan P, Greenwood BM, Whittle H, Mulholland K. 1998. The clinical spectrum of respiratory syncytial virus disease in the Gambia. Pediatr Infect Dis J 17:224-230. 